\title{
Esthetic rehabilitation with minimally invasive lithium disilicate ceramic veneers
}

\author{
Estetyczna rehabilitacja przy użyciu małoinwazyjnych licówek \\ ceramicznych na bazie dwukrzemianu litu
}

\author{
Michal Krump \\ Private Dental Practice, Slovak Republic \\ Praktyka Prywatna, Słowacja
}

KEY WORDS:

ceramic veneers, conservative preparation, diastema closure, esthetic dentistry, lithium disilicate

\section{Summary}

The presence of a space, or a diastema, between anterior teeth, is a common feature of adult dentitions. There are many techniques and materials that can be employed to close diastematas. Ceramic veneers represent a suitable option to correct the shape, symmetry and size of anterior teeth, and can also be used for diastema closure. Improved mechanical properties of lithium disilicate ceramic material allows the production of thin and highly esthetic veneers using a minimally invasive approach. This article reports a case of diastema closure using lithium disilicate ceramic veneers. A 25-year-old female patient sought treatment on a private basis complaining about the shape and spaces between her maxillary anterior teeth. After clinical examination and preliminary procedures, the veneer preparation was carried out. The next phase involved taking the impression at the same appointment, using additional silicone (Variotime, Kulzer). In the laboratory, the lithium disilicate ceramic (IPS e.max Press A1 HT, Ivoclar Vivadent) was used for fabrication of the veneers. After try-in and adequate surface preparation, a light-cured composite luting cement was used for cementation of the veneers (Variolink Esthetic LC neutral, Ivoclar Vivadent). The use
HASŁA INDEKSOWE:

licówki ceramiczne, preparacja zachowawcza, zamknięcie diastemy, stomatologia estetyczna, dwukrzemian litu

\section{Streszczenie}

Występowanie odstęu lub diastemy między zębami przednimi jest częsta cecha uzębienia dorostych. Istnieje wiele technik i materiatów, które można zastosować do zamknięcia diastem. Licówki ceramiczne stanowia odpowiednia opcje korygowania ksztaltu, symetrii $i$ wielkości zębów przednich $i$ moga być równiez stosowane do zamykania diastemy. Ulepszone właściwości mechaniczne materiatu ceramicznego na bazie dwukrzemianu litu pozwalaja na wykonanie cienkich $i$ bardzo estetycznych licówek przy zastosowaniu małoinwazyjnego podejścia. $W$ artykule opisano przypadek zamknięcia diastemy przy użyciu licówek ceramicznych na bazie dwukrzemianu litu. 25-letnia pacjentka zglosita się do prywatnego gabinetu, skarżąc się na ksztalt i przestrzenie między przednimi zębami szczęki. Po badaniu klinicznym i zabiegach wstepnych wykonano preparacje licówek. Kolejna faza obejmowata wycisk na tej samej wizycie z zastosowaniem silikonu addycyjnego (Variotime, Kulzer). W laboratorium do wykonania licówek użyto ceramiki na bazie dwukrzemianu litu (IPS e.max Press AI HT, Ivoclar Vivadent). Po kontroli i odpowiedniej obróbce powierzchni zastosowano światloutwardzalny kompozytowy cement do cementowania licówek (Variolink Esthetic LC neutralny, Ivoclar 
of thin ceramic veneers with minimally invasive preparation represents a conservative approach for highly esthetic rehabilitation of diastematas.

\section{Introduction}

The presence of a space, or diastema, between anterior teeth is a common feature of adult dentitions with a higher prevalence in the maxilla than in the mandible. ${ }^{1}$

Many forms of therapy can be used for diastema closure, such as orthodontic intervention, direct and indirect restorative treatments or their combination. 2,3

While a single and isolated problem can be easily restored with direct application of composite resins, in the case of multiple diastematas, direct composite reconstruction can result in adverse effect on marginal periodontal health because of increased plaque retention. ${ }^{4}$

Moreover, in extensive tooth reconstructions, composites have a high failure rate,

which include fracture, marginal defects, pigment impregnation and color instability. ${ }^{5,6}$

By contrast, ceramic veneers provide biomimetic recovery of the crown with excellent tissue response and surface very similar to that of the natural tooth. ${ }^{7,8}$

Improvements in dental materials have made ceramic reconstruction a suitable approach for indirect esthetic restorations. Lithium disilicate ceramic material consists of a glass matrix highly filled with lithium silicate, with micron-size lithium disilicate crystals in between. ${ }^{9,10}$ Crystallization of lithium disilicate is heterogenous and can be achieved through two different processing routes, depending on whether the glass-ceramic is intended to be used as a machinable block for the CAD/CAM milling technique or as a pressable ingot for the lost wax hot pressing technique. For the
Vivadent). Użycie cienkich licówek ceramicznych z minimalnie inwazyjna preparacja stanowi zachowawcze podejście do wysoce estetycznej korekty diastem.

manufacture of restorations using the lost wax hot pressing technique, a two-stage crystallization process is used to crystalize lithium disilicate. As a result of this process, 3 to $6 \mu \mathrm{m}$-long needle-like crystals of lithium disilicate are formed in a volume fraction of about $70 \% .^{11}$ These elongated crystals significantly increase the materials strength (400 $\mathrm{MPa})$ and despite a high crystalline content, the low refractive index of the lithium disilicate crystals allows the material to maintain a high translucency. ${ }^{17}$ The second generation of lithium disilicatebased materials (IPS e.max Press) can be used for minimally invasive preparations whereby a material thickness of only $0.3 \mathrm{~mm}$ must be observed for veneers. The hot-press ingots are available in various colors and translucencies. The ingot is heated to a temperature that allows the viscous material to flow under pressure into the lost wax mold. This ceramic system allows the fabrication of fully contoured restorations that can be characterized with stains and glazed or veneered using the cut-back technique. The advantage of this system is an improved marginal adaptation, accuracy and fit.

This pressable ceramic system which allows the production of thin and highly esthetic veneers was used in the present clinical case using conservative approach of diastema closure.

\section{Case description and results}

A25-year-old female patient sought treatment on a private basis complaining about the shape and spaces between her maxillary anterior teeth (Fig. 1, 2). Clinical examination of the patient revealed good oral hygiene, teeth without caries 


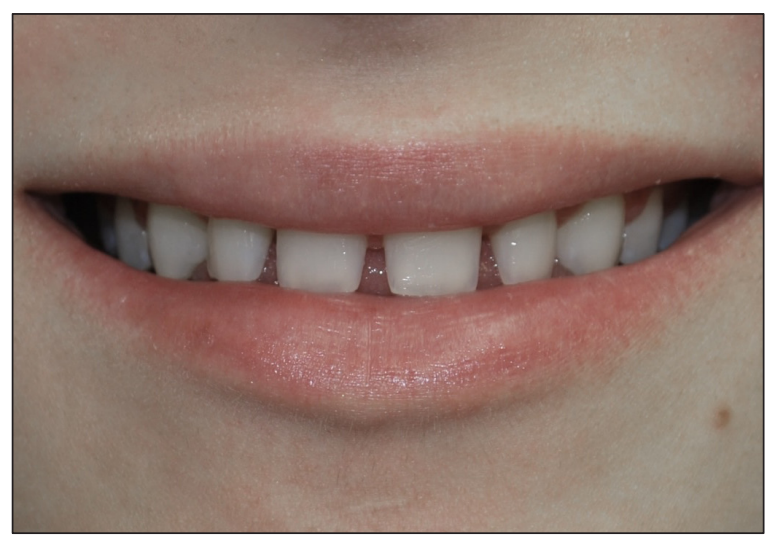

Fig. 1. Preoperative view: the patient's request included the closing of interdental spaces between maxillary incisors. The patient with high position of her lower lip is trying to hide her teeth.

or periodontal diseases. Based on evaluation, indirect treatment approach using thin lithium disilicate ceramic veneers was selected.

Digital photography was performed to provide diagnostic information to the restorative team, such as visualization and quantification of a patient's smile as well as characterization and surface texture evaluation. ${ }^{17}$

The color shade was selected using a IPS e.max Shade Guide (Ivoclar Vivadent). The first phase of the veneer preparation involved the use of round-end diamond bur with 1.0 $\mathrm{mm}$ diameter to create three facial reduction grooves. The grooves were subsequently evened using the cylindric diamond bur with a larger diameter, which prevents the formation of wavy surfaces. ${ }^{18}$ The gingival margin was prepared to $0.3 \mathrm{~mm}$ chamfer and was placed slightly above the level of the gingival crest. A conservative facial reduction was 0.3 to 0.5 $\mathrm{mm}$. The $1 \mathrm{~mm}$ incisal reduction with butt joint design was subsequently carried out. The veneer preparation and depth of reduction was controlled using the silicon index.

The next phase consisted of the extended interproximal preparation, which allowed the dental technician to generate emergence profile for optimal interdental closure. Extra-fine

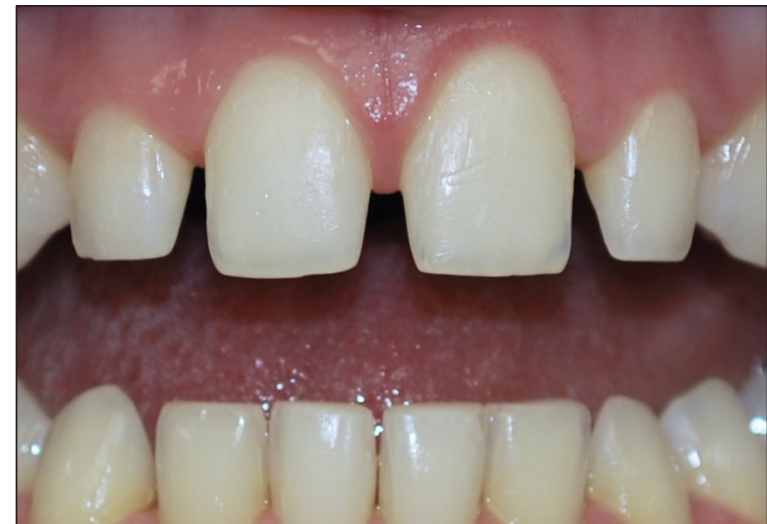

Fig. 2. Preoperative intraoral view.

finishing diamonds were subsequently used to obtain smooth contours.

The next phase involved the impression at the same appointment, using addition silicone (Variotime, Kulzer). A double-cord technique was used for gingival deflection, which included placement of a compression cord of small diameter in the bottom of the sulcus and then more superficial insertion of the deflection cord. The deflection cord was removed just before the impression was taken.

In the laboratory, the lithium disilicate ceramic (IPS e.max Press A1 HT, Ivoclar Vivadent) was used for fabrication of the veneers (Fig. 3, 4). The ingot was hot pressed at $915^{\circ} \mathrm{C}$ to flow viscously into the dental mold made by the lost wax technique to form the restorations, and was held at this temperature for $15 \mathrm{~min}$. The fully contoured restorations were further characterized with stains and glazed. The luting procedures were initially performed using a try-in test paste to select the best shade option (Variolink Esthetic TryIn-Paste, Ivoclar Vivadent). After try-in the veneers were thoroughly rinsed with water spray and carefully air-dried. The interior surfaces of the veneers were etched with $9 \%$ buffered hydrofluoric acid (Porcelain Etch, 


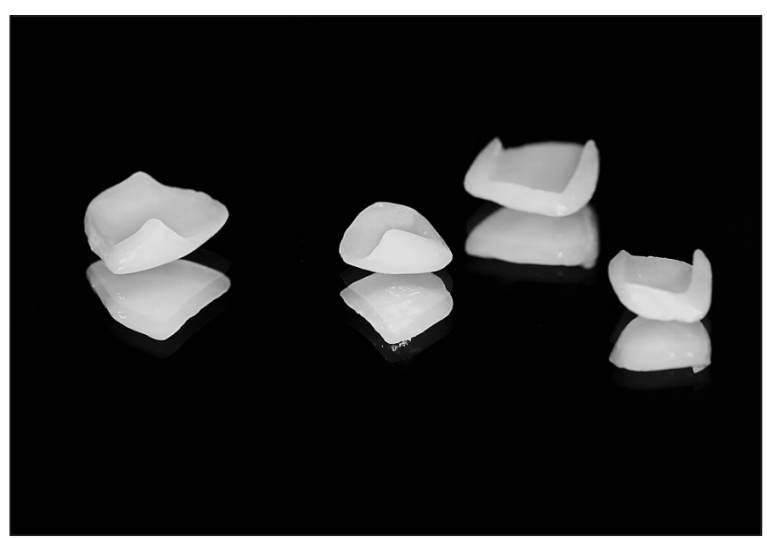

Fig. 3. Fabricated lithium disilicate ceramic veneers.

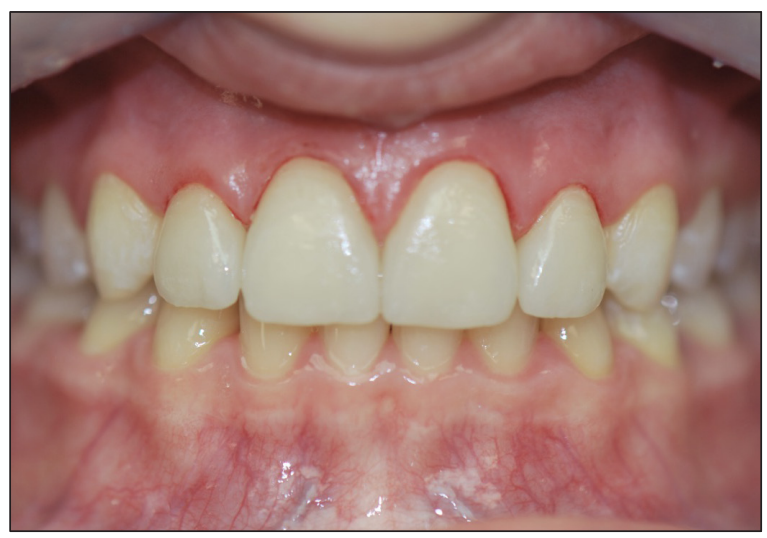

Fig. 5. Intraoral photo immediately after cementation.

Ultradent Products, Inc.) for 20 seconds to create surface roughness, followed by rinsing and air-drying. A silane agent was then applied to the etched ceramic surface of the veneers and air-dried. (Monobond plus, Ivoclar Vivadent). The gingival displacement was acquired using a retraction cord. Subsequently, adequate surface treatment for the dental tissues was done. The teeth were cleaned using fluoridefree cleaning paste (Proxyt, fluoride-free prophy paste, Ivoclar Vivadent), rinsed and airdried. Each preparation was etched with $35 \%$ phosphoric acid for 15 seconds, then rinsed for 5 seconds and air-dried. A light curing adhesive was rubbed into the preparation surface for 20 seconds and then dispersed with compressed air (Adhese Universal VivaPen, Ivoclar Vivadent).

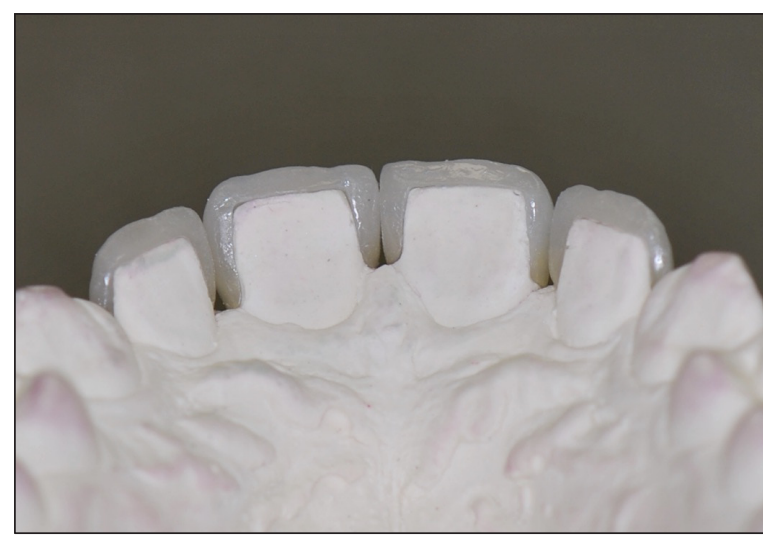

Fig. 4. Palatal view of the final restorations.

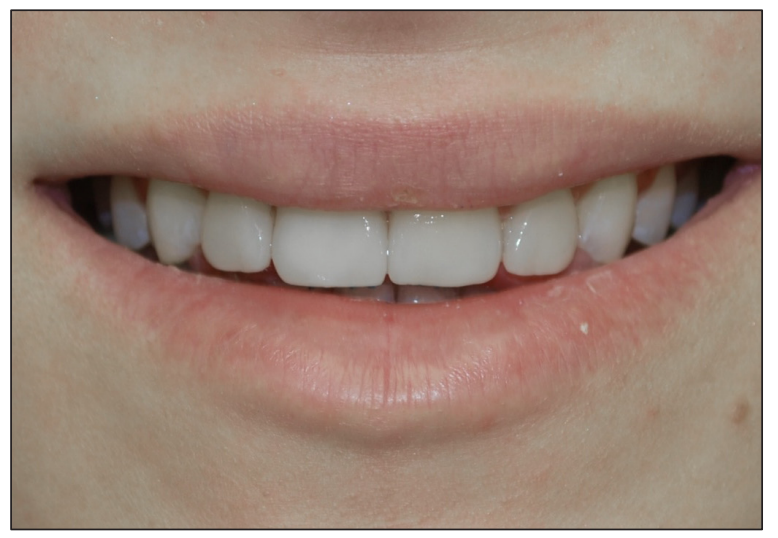

Fig. 6. Patient's smile 3 months after cementation. Note the lower lip position and "uncovering" the smile when compared with Fig. 1.

Subsequently, polymerization was performed for 10 seconds $\left(1400 \mathrm{~mW} / \mathrm{cm}^{2}\right)$. The light-cured composite cement in neutral shade (Variolink Esthetic LC neutral, Ivoclar Vivadent) was applied onto prepared internal surface of each ceramic veneer that were gently seated with finger pressure. The excess cement was polymerized for 2 seconds and then removed with a scaler (circular technique). Immediately after excess removal, the restoration margins were covered with glycerine gel. Polymerization was performed from the facial, lingual and incisal aspects for 10 seconds each (light intensity of $1400 \mathrm{~mW} / \mathrm{cm}^{2}$ ). After polymerization, the glycerine gel was rinsed off. Subsequently, the excess of polymerized cement was removed using scalpel blade and unwaxed floss. 
Finally, the finishing and polishing were done (Fig. 5).

After 3 months a follow-up revealed significant improvement in the patient's dentofacial composition with considerable impact on the patient's confidence (Fig. 6).

\section{Discussion}

The specific goals of treating diastema involve creating a tooth form in harmony with the adjacent teeth, arch and facial form. Esthetic rehabilitation requires the correct diagnosis and planning depending on the size of diastema. ${ }^{19}$ Although direct restoration with composite resins has advantages such as its conservative approach and low cost, indirect techniques in design of the ceramic veneers present excellent optical properties, compressive strength, surface smoothness, abrasion resistance, gloss and color stability. ${ }^{20,21}$ Improved mechanical properties of lithium disilicate ceramic material allow the production of thin, highly esthetic veneers with minimum reduction of dental tissues. ${ }^{9,22}$ On the other hand, due to the thinness, these veneers have limited ability for masking color changes of the teeth. ${ }^{23}$

The recovery of function and smile esthetics of a patient with diastema with thin ceramic veneers allowed conservative approach. In the cases when color of the restored teeth does not require masking, thin lithium disilicate veneers provide highly esthetic results.

\section{References / Piśmiennictwo}

1. Keene HJ: Distribution of diastemas in the dentition of man. Am J Phys Anthropol 1963; 21: 437-441.

2. Signore A, Kaitsas V, Tonoli, et al.: Sectional porcelain veneers for a maxillary midline diastema closure: a case report. Quintessence Int 2013; 44: 201-206.

3. Oquendo A, Brea L, David S: Diastema: correction of excessive spaces in the esthetic zone. Dent Clin North Am 2011; 55: 265-281.

4. Peumans M, Van Meerbeek B, Lambrechts $P$, Vanherle $G$, Quirynen M: The influence of direct composite additions for the correction of tooth form and/or position on periodontal health: A retrospective study. J Periodontol 1998; 69: 422-427.

5. Garoushi S, Lasilla L, Hatem M, et al.: Influence of staining solutions and whitening procedures on discoloration of hybrid composite resins. Acta Odontol Scand 2013; 71: 144-150.

6. Tuncer D, Yacizi A, Ozgunaltay G, Dayangac $B$ : Clinical evaluation of different adhesives used in restoration of non-carious cevical lesions: 24-month results. Aust Dent J 2013; 58: 94-100.

7. Pereira $L M$, Resende CCD, Tavares $L N$, et al.: Esthetic rehabilitation of smile with minimally invasive preparations and thin laminate ceramic veneers using chairside cad/ cam system. J Dent Health Oral Disord Ther 2017; 8: 426-430.

8. Viswambaran $M$, Londhe SM, Kumar $V$ : Conservative and esthetic management of diastema closure using porcelain laminate veneers. Med J Armed Forces India 2015; 71: 581-585.

9. Santos MJ, Costa MD, Rubo JH, Pegoraro $L F$, Santos GC Jr.: Curent all-ceramic systems in dentistry: A review. Compend Contin Educ Dent 2015; 36: 31-38.

10. Oh SC, Dong JK, Luthy H, Scharer P: Strength and microstructure of IPS Empress 2 glass-ceramic after different treatments. Int $\mathrm{J}$ Prosthodont 2000; 13: 468-472. 
11. Shen JZ, Kosmač T: Advanced Ceramics for Dentistry. Oxford: Butterworth-Heinemann 2013: 255-277.

12. Zarone F, Ferrari M, Mangano FG, Leone $R$, Sorrentino $R$ : Digitally oriented materials: Focus on lithium disilicate ceramics. Int $\mathrm{J}$ Dent 2016; 2016: 1-10.

13. Albakry M, Guazzato M, Sain MV: Biaxial flexural strength, elastic moduli, and x-ray diffraction characterization of three pressable all-ceramic material. J Prosthet Dent 2003; 89: 374-380.

14. Kelly JR, Benetti P: Ceramic materials in dentistry: Historical evolution and current practice. Aust Dent J 2011; 56 (suppl): 84-96.

15. Terry DA, Geller W: Esthetic and Restorative Dentistry. Material selection and Technique, 3rd edn. Illinois: Quintessence Publishing 2018: 160-161.

16. Kelly JR, Nishimura I, Campbell SD: Ceramics in dentistry: historical roots and current perspectives. J Prosthet Dent 1996; 75: 18-32.

17. Terry DA, Geller W: Esthetic and Restorative Dentistry. Material selection and Technique, 3rd edn. Illinois: Quintessence Publishing 2018: 12-17.

18. Magne P, Belser $U$ : Bonded Porcelain Restorations in the anterior dentition. A biomimetic approach. Illinois: Quintessence
Publishing 2003: 242-246.

19. Baratieri LN, Araujo EM Jr., Monteiro S. Jr.: Composite restorations in anterior teeth: fundamentals and possibilities. Chicago: Quintessence 2005; 3-82.

20. De Andrade OS, Hirata R, Celestrino $M$, et al. Ultimate Ceramic Veneer: A LaboratoryGuided Preparation Technique for Minimally Invasive Laminate Veneers. J Calif Dent Assoc 2012; 40: 489-494.

21. De Andrade OS, Ferreira LA, Hirata $R$, Rodrigues FP, D'Alpino PH, Di Hipolito $V$ : Esthetic and functional rehabilitation of crowded mandibular anterior teeth using ceramic veneers: a case report. Quintessence Int 2012; 43: 661-670.

22. Soares PV, Spini PH, Carvalho VF, et al. Esthetic rehabilitation with laminated ceramic veneers reinforced by lithium disilicate. Quintessence Int 2014; 45: 129-133.

23. Dozic A, Tsagkari M, Khashayar G, Aboushelib $M$ : Color management of porcelain veneers: influence of dentin and resin cement colors. Quintessence Int 2010; 41: 567-573.

Zaakceptowano do druku: 15.12.2020 r.

Adres autora: Private Dental Practice, Púchov, Slovak Republic; email: michalkrump@gmail.com

C Zarząd Główny PTS 2021. 